\title{
CEMENT THICKNESS OF POST AND CORES FABRICATED BY MODERN DIGITAL TECHNOLOGY
}

\author{
DEBELINA CEMENTA PRI ZATIČKIH Z NAZIDKI, IZDELANIH S \\ SODOBNO DIGITALNO TEHNOLOGIJO
}

\author{
Domen Kanduti ${ }^{1 *}$, Igor Kopač ${ }^{2}$ \\ ${ }^{1}$ University of Ljubljana, Faculty of Medicine, Department for Oral Diseases and Periodontology, Dental Clinic, \\ Hrvatski trg 6, 1000 Ljubljana, Slovenia \\ ${ }^{2}$ University of Ljubljana, Faculty of Medicine, Prosthodontics Department, Dental Clinic, Hrvatski trg 6, 1000 Ljubljana, Slovenia
}

Prejem rokopisa - received: 2019-06-09; sprejem za objavo - accepted for publication: 2020-07-24

doi:10.17222/mit.2020.136

Computer-assisted digital (CAD-CAM) technologies in prosthodontics can be used for the fabrication of posts and cores. Digital techniques shorten the necessary clinical and laboratory procedures and make fabrication easier, quicker and accurate. Extracted single-rooted permanent maxillary incisors were used in the study. For each tooth one metal post was fabricated with a digital technique using SLM fabrication technology (group A) or one by casting (group B) in randomized tooth order. All the posts were cemented with zinc phosphate cement. All the teeth were sliced perpendicular to the axis of the post in four planes. The thickness of the cement layer was measured on four slices with an optical microscope with $60 \times$ and $100 \times$ magnification lens and was compared between both groups. The average cement thickness for group A was $36.76 \pm 17.29 \mu \mathrm{m}$ in cross-section 1 , $62.38 \pm 15.24 \mu \mathrm{m}$ in cross-section $2,129.42 \pm 38.37 \mu \mathrm{m}$ in cross-section 3 , and $142.76 \pm 36.35 \mu \mathrm{m}$ in cross-section 4 . For group B the average cement thickness was $18.18 \pm 4.6 \mu \mathrm{m}$ in cross-section $1,15.36 \pm 5.41 \mu \mathrm{m}$ in cross-section $2,25.41 \pm 13.42 \mu \mathrm{m}$ in cross-section 3, and $23.69 \pm 13.44 \mu \mathrm{m}$ in cross-section 4 . The CAD-CAM post and core fabrication technique had a significantly larger cement thickness in all cross-sections compared to casting; however, the post accuracy was still within a clinically acceptable range.

Keywords:post and core, metal casting, CAD-CAM, selective laser melting

Računalniško podprte tehnologije oblikovanja in izdelave (CAD-CAM) so danes na področju stomatološke protetike v uporabi tudi za izdelavo zatičkov z nazidki, kar skrajša celoten čas kliničnih in laboratorijskih postopkov in omogoča lažjo, hitrejšo in natančno izdelavo. V raziskavi so bili uporabljeni ekstrahirani enokoreninski zgornji stalni sekalci. Za vsak zob je bil v naključnem vrstnem redu izdelan en zatiček z nazidkom po digitalni metodi, z uporabo SLM tehnologije (skupina A) ali ulit zatiček z nazidkom (skupina B). Zatički so bili cementirani s cink-fosfatnim cementom, vsi zobje pa razrezani na rezine pravokotno na os zatička. Debelina cementa je bila izmerjena z optičnim mikroskopom s 60-kratno in 100 -kratno povečavo objektiva in primerjana med skupinama. Rezultati so pokazali, da je bila povprečna debelina cementa za skupno A 36,76 $\pm 17,29$ $\mu \mathrm{m}$ na prerezu $1,62,38 \pm 15,24 \mu \mathrm{m}$ na prerezu $2129,42 \pm 38,37 \mu \mathrm{m}$ na prerezu 3 in $142,76 \pm 36,35 \mu \mathrm{m}$ na prerezu 4 . Za skupino B je bila povprečna debelina cementa $18,18 \pm 4,6 \mu$ m na prerezu $1,15,36 \pm 5,41 \mu \mathrm{m}$ na prerezu $225,41 \pm 13,42 \mu \mathrm{m}$ na prerezu 3 in $23,69 \pm 13,44 \mu \mathrm{m}$ na prerezu 4. Uporabljena CAD-CAM izdelava zatičkov z nazidki je imela statistično značilno večjo debelino cementne špranje na vseh prerezih, vendar se izkazala za klinično sprejemljivo natančno metodo izdelave.

Ključne besede: zatiček z nazidkom, izlitje v kovini, CAD-CAM, selektivno lasersko nataljevanje

\section{INTRODUCTION}

Teeth with extensive loss of hard dental tissues have a significant reduction in their fracture resistance. ${ }^{1}$ Therefore, several different techniques and materials are available for restoring such teeth. ${ }^{2}$ Post and core restoration allows the replacement of the missing coronal hard tissues and provides support and retention of the final prosthodontic crown. ${ }^{3}$

With the development of digital technologies in the last two decades, different methods of computer-aided design/computer-aided manufacturing (CAD-CAM) were introduced in dentistry. They enabled the fabrication of different prosthetic restorations, including post and core. CAM can be divided into subtraction methods (material removal by milling from a larger block of ma-

*Corresponding author's e-mail:

domen.kanduti@mf.uni-1j.si (Domen Kanduti) terial) and additive methods (material added by layers). Selective laser melting (SLM) is an additive technique used for the fabrication of different metal restorations and frameworks. ${ }^{4,5}$ The materials of choice for the SLM are steel, titanium, titanium alloys and Co-Cr alloys. ${ }^{5}$

For the fabrication of the post and core, different CAD-CAM solutions are described in the literature. They are all partially digital as they combine classic and digital workflows. Most of them include classic impression techniques and an extra-oral scan of an acrylic model of the post and core or an extraoral scan of the silicon impression of the post space in combination with the CAD-CAM. Some are combinations of a prefabricated post and a CAD-CAM-fabricated core, luted together directly in the prepared tooth. ${ }^{6-8}$ In 2013, a fully digital CAD solution was introduced for post and core fabrication (Trios Post and Core, 3SHAPE, Denmark). They have developed special scanning abutments/posts 
(Scan Posts) of various shapes and sizes, which are inserted into the prepared root canal and scanned according to the manufacturer's instructions. They are suitable for both intra-oral and laboratory use. According to the scan data, the CAD software automatically forms a post space based on the selected Scan Post cervical part of the root-canal walls that are scanned separately. In the second step, the technician designs the core according to the final restoration of the tooth and the space available to the antagonists. This is followed by the fabrication with $3 \mathrm{D}$ wax printing and precision casting in metal, milling or SLM in metal. ${ }^{9}$

Most of the research testing or comparing different post-and-core restorations are designed as in-vitro studies. The authors usually focus on assessing the retention of the post and the fracture resistance of the teeth with cemented posts. The frequency and severity of both complications depend on several factors. One is an optimal post fit with the shape of the prepared root canal with a maximum possible thickness of the remaining dentin walls. ${ }^{10,11}$ Various studies have shown that the optimal fit of the post is especially important in the cervical part of the root canal, as they find that the lateral and oblique force concentration in the cervical part is the greatest. ${ }^{12}$ An optimal cement thickness in the cervical part is also important for hermetic root-canal closure. An increased cement thickness results in increased micro leakage and thus adversely affects the clinical outcome of such restorations. ${ }^{13,14}$ The aim of this study was to compare the cement thickness of the posts manufactured with a precision casting technique and those fabricated by using Scan Posts and the SLM technique. Our hypothesis was that the fabrication of a post with the use of Scan Posts, intra-oral scanning and SLM technology is as accurate as the fabrication of posts with the direct technique, using an acrylic resin pattern and casting.

\section{MATERIALS AND METHODS}

The study was performed under in-vitro laboratory conditions. Ten non-carious extracted permanent upper incisors were used with an intact root canal without pathological and anatomical features. All the teeth were endodontically treated. The preparation of the root canals was performed 1-2 weeks after the obturation of the root canals. The teeth were randomly divided into group A $(n=5)$ and group $\mathrm{B}(n=5)$.

Group A: According to the manufacturers' instructions, Scan Posts support drilling systems from major suppliers and are not included in the 3SHAPE CAD solution. For this study, a Scan Post 1.7 APL (Scan posts, 3SHAPE, Denmark) and a dimension-appropriate (apical diameter: $1 \mathrm{~mm} /$ diameter of the widest part 1.67 $\mathrm{mm} /$ length of the active conical part: $7.6 \mathrm{~mm}$ ) calibration drill (special calibration drill, blue mark, no. 110, Maillefer, Dentsply, USA) were chosen. All the teeth were carefully prepared up to a depth of $10 \mathrm{~mm}$ and a passive fit of Scan Post. For each tooth the post and core were fabricated using the 3Shape post-and-core CAD solution and SLM technology. All the teeth were scanned with an intraoral scanner (Trios, 3SHAPE, Denmark) according to the manufacturer's instructions (Figure 1, I). The coronal part and the prepared root canal of each tooth were scanned with a first scan. A second scan was made with the chosen Scan Post (1.7 APL), passively inserted into the prepared root canal. The CAD software Dental System ${ }^{\circledR}$ (3Shape, Denmark) was used for the post-and-core design (Figure 1, I-IV).

After importing both scans, they were superimposed by a three-point alignment. The program automatically calculates the position and depth of the selected Scan Post and shapes the post space accordingly. The cement gap was determined to be $5 \mu \mathrm{m}$. After modelling a core, a final shape and model of the post and core was saved in the .stl (stereolithographic) format and sent for SLM fabrication - 3D printing (Mlab cusing, Concept Laser

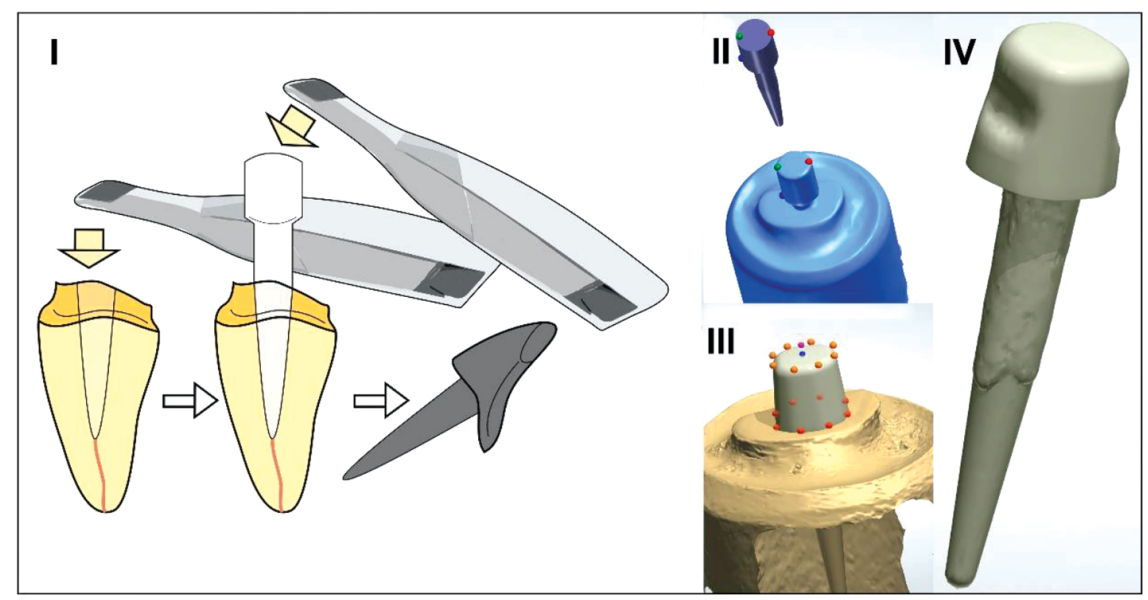

Figure 1: Schematical demonstration of 3SHAPE CAD Scan Post solution - scanning: I - sample of prepared tooth for first 3D scan, sample of tooth with Scan Post inserted into prepared canal for second 3D scan; II selection of used Scan Post in software and three-point alignment; III; design of core; IV - 3D post model. 
GmbH, Germany) using Co-Cr alloy (Remanium® star CL, Dentaurum, Germany).

Group B: All the teeth were carefully prepared to a depth of $10 \mathrm{~mm}$ using the same calibration drill (special calibration drill, blue mark, no. 110, Maillefer, Dentsply, USA). The post-and-core patterns were fabricated using auto-polymerizing acrylic resin (Pattern $\operatorname{Resin}^{\mathrm{TM}} \mathrm{LS}, \mathrm{GC}$, Japan) and prefabricated plastic posts (uniclip plastic post, Maillefer, Dentsply, USA). All the acrylic patterns were invested (FujiVest, GC, Japan) and cast from a Co-Cr alloy (Biostar S, Aurodent, Zlatarna Celje, Slovenia) with a precision metal-casting technique.

After fabrication the posts and cores were cemented using zinc phosphate cement (normal setting, Harvard cement, Harvard, Germany).

All the teeth from both groups were, after cementation of the posts and cores, inserted into the clear cold polymerizing acrylic resin cylindrical block (Pro base, clear, Ivoclar Vivadent, Liechtenstein). After the setting of the acrylic resin, blocks were cut using an electric precision saw (Isomet 1000, precision saw, Buehler, USA) with a blade (IsoCut CBN LC, Buehler, USA) transversely into four 2-mm-thick that were sliced perpendicular to the axis of the post and core (Figure 2).

All the cut surfaces were polished by machine (Phoenix 1000, Buehler, USA) under continuous water admission using sandpaper (Carbimet, Buehler, USA) with a gradation of 600 . Polishing removed the metal deposits present in the cement layer, which would interfere with the measurements of the cement thickness. Each slice was observed under an optical microscope (Eclipse E600, Nikon, Japan) with a $60 \times$ and a $100 \times$ lens
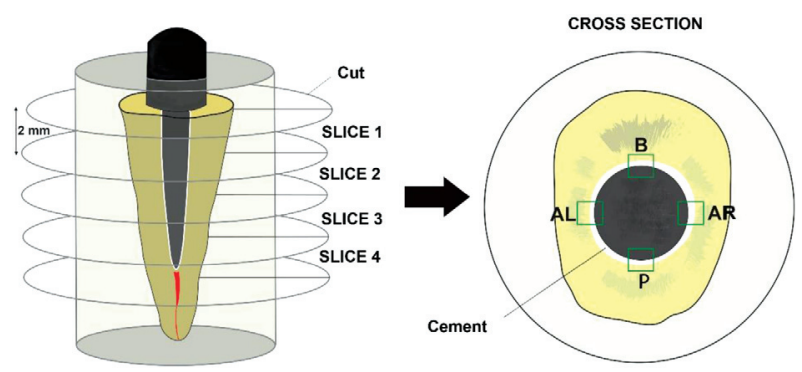

Figure 2: Schematic demonstration of slices and cross-section with four sites chosen for measuring a cement thickness: B - bucal, AD aproximal right, $\mathrm{P}$ - palatal, $\mathrm{AL}$ - aproximal left.

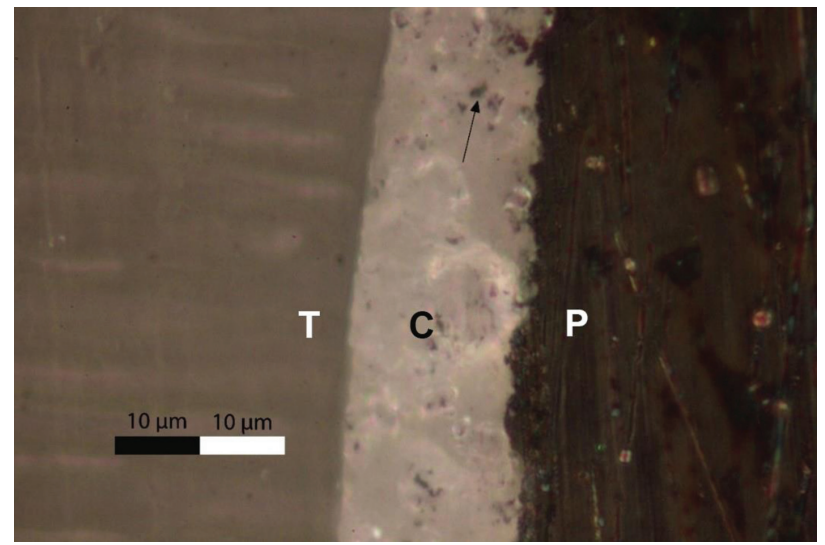

Figure 3: Micrograph of cement (optical microscope with $100 \times$ magnification lens): $\mathrm{T}$ - tooth; $\mathrm{C}$ - cement; $\mathrm{P}$ - Post; Arrow - metal particle.

(Figure 3). Micrographs of each slice were taken under magnification (EOS 550, Canon, Japan) and transferred to a computer. The cement thickness was measured on four sites of each cross-section (Figure 2) using appropriate computer software (ImageJ2).

The greater thickness of the cement layer means a less appropriate fit of the post to the prepared root-canal wall and indicates the lower accuracy of the fabrication method used.

Statistical analyses of the data were performed with SPSS software (IBM SPSS Statistics 22, IBM USA) using the parametric Student-t test and a one-way analysis of variance (ANOVA) with a "post hoc" Bonferroni correction. A $95 \%$ confidence interval was chosen. A statistically significant difference was confirmed when the $p$-value was less than 0.05 .

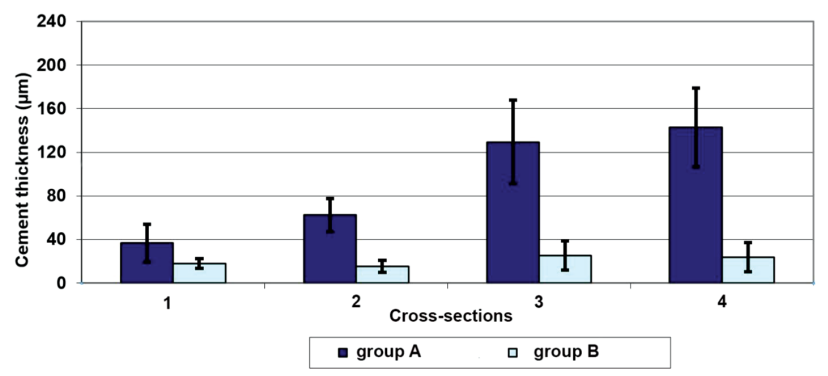

Figure 4: The cement thickness at each cross-section

Table 1: Post-hoc Bonfferoni correction for comparison of the mean cement thickness of all 4 cross-sections for each group separately

\begin{tabular}{|c|c|c|c|c|c|c|c|}
\hline $\begin{array}{l}\text { Post fabrication } \\
\text { method }\end{array}$ & \multicolumn{2}{|c|}{ Cross-section } & $p$-value & $\begin{array}{c}\text { Post fabrication } \\
\text { method }\end{array}$ & \multicolumn{2}{|c|}{ Cross-section } & $p$-value \\
\hline \multirow{9}{*}{$\begin{array}{l}\text { Group A } \\
\text { (Digital) }\end{array}$} & \multirow{3}{*}{$1 *$} & 2 & 1.000 & \multirow{9}{*}{$\begin{array}{l}\text { Group B } \\
\text { (Casting) }\end{array}$} & \multirow{3}{*}{1} & 2 & 1.000 \\
\hline & & 3* & 0.001 & & & 3 & 1.000 \\
\hline & & $4 *$ & 0.000 & & & 4 & 1.000 \\
\hline & \multirow{3}{*}{$2 *$} & 1 & 1.000 & & \multirow{3}{*}{2} & 1 & 1.000 \\
\hline & & $3 *$ & 0.012 & & & 3 & 0.821 \\
\hline & & $4 *$ & 0.003 & & & 4 & 1.000 \\
\hline & \multirow{3}{*}{$3 *$} & $1 *$ & 0.001 & & \multirow{3}{*}{3} & 1 & 1.000 \\
\hline & & $2 *$ & 0.012 & & & 2 & 0.821 \\
\hline & & 4 & 1.000 & & & 4 & 1.000 \\
\hline
\end{tabular}




\section{RESULTS}

The average cement thickness for group A was $36.76 \pm 17.29 \mu \mathrm{m}$ in cross-section $1,62.38 \pm 15.24 \mu \mathrm{m}$ in cross-section $2,129.42 \pm 38.37 \mu \mathrm{m}$ in cross-section 3 , and $142.76 \pm 36.35 \mu \mathrm{m}$ in cross-section 4 . For group B the average cement thickness was $18.18 \pm 4.6 \mu \mathrm{m}$ in cross-section $1,15.36 \pm 5.41 \mu \mathrm{m}$ in cross-section $2,25.41 \pm 13.42$ $\mu \mathrm{m}$ in cross-section 3 , and $23.69 \pm 13.44 \mu \mathrm{m}$ in cross-section 4 . In the second part, we calculated the mean \pm SD of the cement thickness of each cross-section separately. The mean \pm SD of the cement thickness for both groups and each cross-section are shown in Figure 4. The differences between both groups were statistically significant in all 4 cross-sections $1(p=0.049), 2(p=0.001), 3$ $(p<0.001)$ in $4(p=0.009)$.

A one-way statistical ANOVA test with post-hoc Bonfferoni correction compared the mean cement thickness values of all 4 cross-sections for each group separately (Table 1). In group A the cement thickness at cross-sections 1 and 2 differed statistically significantly compared to sections 3 and 4 . The differences between the remaining cross-sections and all the cross-sections in group B were statistically insignificant.

\section{DISCUSSION}

CAD-CAM digital technologies are becoming an indispensable part of modern dentistry, especially in the prosthodontics. This study aimed to compare the cement thickness of metallic posts and cores fabricated by casting or using the modern CAD-CAM technique with Scan Posts, intra-oral scanning, and SLM fabrication. For a standardized accuracy assessment, this study was conducted under controlled and standardized laboratory conditions (in vitro). Even though in-vitro conditions cannot replicate the clinical situation completely, they are more appropriate for studying accuracy using methods not applicable to a clinical study. ${ }^{15,16}$ Throughout the study, we followed a strict handling protocol to prevent tooth drying. ${ }^{17}$

The evaluation of accuracy when measuring cement thickness was possible because the cement layer was homogeneous in all sections. No voids, inclusions or inconsistencies at the border between the cement and the root-canal wall or cement and post were found under magnification. All the measured cement thicknesses corresponded to the distance between the surface of the post and the root-canal wall. From the clinical criteria the cement thickness in cross-section 1 was comparable for both groups of samples, despite a statistically significant difference. In all other three cross-sections the cement thickness was significantly greater in group A in comparison to group B. The posts in group B had significantly more congruent form in comparison to the group A posts. The largest thicknesses in group A were measured in apical sections (cross-sections 3 and 4) as can be seen in Figure 4. These statistically significant differences can be attributed to findings that the intraoral scanner successfully captures the cervical part of the root canal. This part of the post is therefore congruent and individually fitted to the canal walls and the cement thickness is smaller in comparison to the apical part of the post where the post shape corresponds to the shape of the selected Scan Post. Therefore, the accuracy or post fit to the prepared root-canal wall depends greatly on the combination Scan Post and the calibration drill used for the preparation. The manufacturer states that Scan Posts support drill systems from major suppliers that are already in clinical use and are not included in the system. There are no known recommendations or suggestions from other producers of drill systems and there are no known studies regarding this topic.

According to the literature, the accuracy of the post fit to the prepared root canal walls is an important clinical parameter that contributes to the success of the final restorative outcome, clinical prognosis and improves the fracture resistance of the restored tooth. ${ }^{2,3,6,18}$ Based on the findings of this study and the findings of studies published by other authors who have examined the influence of cement type and thickness on the retention properties of the posts and cores and the fracture resistance of such restored teeth, it can be concluded that the cement thickness of the posts fabricated using the digital method with Scan Posts and SLM fabrication is clinically acceptable and comparable to the classic direct casting fabrication method in the cervical part of the prepared root canal where retention, resistance to lateral and oblique forces and absence of micro-leakage are the most important. According to the findings of this pilot study the manufacturer should include appropriate penetration and calibration drills for root canal preparation or publish more specific recommendations. In our opinion, further research is needed to investigate the post retention and tooth fracture resistance using different cementation techniques.

\section{CONCLUSIONS}

This pilot study is the starting point for further research and a first step in proving the accuracy of the CAD-CAM method using Scan Posts. Despite the clinically acceptable results in a coronal section of post space, a significant difference regarding the cement thickness and therefore accuracy between both methods was determined for the other sections.

\section{Acknowledgements}

The authors gratefully acknowledge the financial support from the Slovenian Research Agency (research core funding No. IP-0510). The authors would also like to thank Milan Števanec for help with statistical analysis and all others who contributed to this research. 


\section{KANDUTI, I. KOPAČ: CEMENT THICKNESS OF POST AND CORES FABRICATED BY MODERN DIGITAL TECHNOLOGY}

\section{REFERENCES}

${ }^{1}$ J. Rus, I. Kopač, Oskrba endodontsko zdravljenih zob, Zbornik 21. simpozija Sekcije za stomatološko protetiko, 2015, 21, str. 17-25

${ }^{2}$ J. N. Theodosopoulou, K. M. Chochlidakis, Systematic review of dowel (post) and core erials. J. Prosthodont. 18, 6 (2009) 464-472, doi:10.1111/j.1532-849X.2009.00472.x

${ }^{3}$ R. S. Schwartz, J. W. Robbins, Post placement and restoration of endodontically treated teeth: a literature review, J. Endod. 30, 5 (2004) 289-301, doi:10.1097/00004770-200405000-00001

${ }^{4}$ M. S. Bilgin, A. Erdem, E. Dilber, Comparison of fracture resistance between cast, CAD/CAM milling, and direct metal laser sintering metal post systems, J Prosthodont Res. 60 (2016) 1, 23-28, doi:10.1016/j.jpor.2015.08.001

${ }^{5} \mathrm{R}$. Van Noort, The future of dental devices is digital, Dent. Mater. 28 , (2012) 3-12, doi:10.1016/j.dental.2011.10.014

${ }^{6}$ T. Y. Marghalani, M. T. Hamed, M. A. Awad, three-dimensional finite element analysis of custom-made ceramic dowel made using CAD/CAM technology, J. Prosthodont., 21 (2012) 6, 440-450, doi:10.1111/j.1532-849X.2012.00860.x

${ }^{7}$ Z. Chen, Y. Li, X. Deng, X. Wang, A novel computer-aided method to fabricate a custom one-piece glass fiber dowel-and-core based on digitized impression and crown preparation data, J Prosthodont, 23, (2014) 4, 276-83, doi:10.1111/jopr.12102

${ }^{8} \mathrm{~J}$. H. Lee, Accelerated techniques for a post and core and a crown restoration with intraoral digital scanners and CAD/CAM and rapid prototyping, J. Prosthet Dent. 112, 5 (2014) 1024-1029, doi:10.1016/j.prosdent.2014.01.015

${ }^{9}$ F. B. Mendel, 3Shape releases CAD solution for post and core restorations, Dental Tribune Middle East \& Africa Edition, 5 (2013) 2, 16

${ }^{10}$ M. K. Al-Omiri, A. A. Mahmoud, M. R. Rayyan, Fracture resistance of teeth restored with post-retained restorations: an overview, J Endod. 36, (2010) 9, 1439-1449, doi:10.1016/j.joen.2010.06.005
${ }^{11}$ W. Tang, Y. Wu, R. J. Smales, Identifying and reducing risks for potential fractures in endodontically treated teeth, J Endod. 36 (2010)4, 609-17, doi:10.1016/j.joen.2009.12.002

${ }^{12}$ D. C. Holmes, A. M. Diaz-Arnold, J. M. Leary, Influence of post dimension on stress distribution in dentin, J. Prosthet. Dent. 75 (1996) 140-1477, doi:10.1016/s0022-3913(96)90090-6

${ }^{13}$ S. Ravanshad, N. Ghoreeshi, An in vitro study of coronal microleakage in endodontically-treated teeth restored with posts, Aust. Endod J 29,3 (2003) 128-33, doi:10.1111/j.1747-4477.2003. tb00536.x

${ }^{14}$ S. Erkut, K. Gulsahi, A. Caglar, Microleakage in overflared root canals restored with different fiber reinforced dowels, Oper Dent., 33, (2008) 1, 96-105, doi:10.2341/07-47

${ }^{15}$ M. R. Rayyan, R. A. Aldossari, S. F.Alsadun, F. R. Hijazy, Accuracy of cast posts fabricated by the direct and the indirect techniques, J. Prosthet. Dent. 116 (2016) 411-415, doi:10.1016/j.prosdent.2016. 02.002

${ }^{16}$ R. Dautia, B. Cvikla, B. Lilaja, P. Heimelb, A. Moritza, A. Schedlea, Micro-CT evaluation of marginal and internal fit of cemented polymer infiltrated ceramic network material crowns manufactured after conventional and digital impressions, J Prosthodont Res., 63 (2019), 40-46, doi:10.1016/j.jpor.2018.04.005

${ }^{17}$ ISO/TS 11405 Dental materials — Testing of adhesion, ISO, ISO, 3 (2015) 1-12

${ }^{18}$ E. A. Caceres, C. S. Sampaio, P. J. Atria, Void and gap evaluation using microcomputed tomography of different fiber post cementation techniques, J Prosthet Dent., 119 (2017) 103-107, doi:10.1016/ j.prosdent.2017.01.015 